\title{
Ryanodine Receptors, Voltage-Gated Calcium Channels and Their Relationship with Protein Kinase A in the Myocardium
}

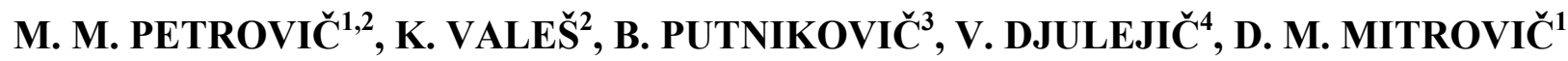 \\ ${ }^{1}$ Institute of Medical Physiology, School of Medicine, Belgrade, Serbia, ${ }^{2}$ Institute of Physiology, \\ Academy of Sciences of the Czech Republic, Prague, Czech Republic, ${ }^{3}$ Cardiology Department, \\ Clinical hospital Center Zemun, School of Medicine, Belgrade and ${ }^{4}$ Institute of Anatomy, School of \\ Medicine, Belgrade, Serbia
}

Received December 1, 2006

Accepted March 15, 2007

On-line available April 25, 2007

\section{Summary}

We present a review about the relationship between ryanodine receptors and voltage-gated calcium channels in myocardium, and also how both of them are related to protein kinase $A$. Ryanodine receptors, which have three subtypes (RyR1-3), are located on the membrane of sarcoplasmic reticulum. Different subtypes of voltage-gated calcium channels interact with ryanodine receptors in skeletal and cardiac muscle tissue. The mechanism of excitation-contraction coupling is therefore different in the skeletal and cardiac muscle. However, in both tissues ryanodine receptors and voltage-gated calcium channels seem to be physically connected. FK-506 binding proteins (FKBPs) are bound to ryanodine receptors, thus allowing their concerted activity, called coupled gating. The activity of both ryanodine receptors and voltage-gated calcium channels is positively regulated by protein kinase A. These effects are, therefore, components of the mechanism of sympathetic stimulation of myocytes. The specificity of this enzyme's targeting is achieved by using different A kinase adapting proteins. Different diseases are related to inborn or acquired changes in ryanodine receptor activity in cardiac myocytes. Mutations in the cardiac ryanodine receptor gene can cause catecholamineprovoked ventricular tachycardia. Changes in phosphorylation state of ryanodine receptors can provide a credible explanation for the development of heart failure. The restoration of their normal level of phosphorylation could explain the positive effect of beta-blockers in the treatment of this disease. In conclusion, molecular interactions of ryanodine receptors and voltage-gated calcium channels with PKA have a significant physiological role.
However, their defects and alterations can result in serious disturbances.

\section{Key words}

Ryanodine receptors - Calcium channels - Protein kinase A • Heart failure

\section{Corresponding author}

M. M. Petrovic, Institute of Physiology, Academy of Sciences of the Czech Republic, Vídeňská 1083, 14220 Prague 4, Czech Republic. E-mail: mp011cz@gmail.com

\section{Introduction}

In general, $\mathrm{Ca}^{2+}$ ions can flow into the cell from the outside, through different types of channels, or they can be released from internal stores. This local increase in cytosolic $\left[\mathrm{Ca}^{2+}\right]$ that creates a microdomain is used by various systems to start distinct events in the cell. (Fill and Copello 2002). Ryanodine receptors (RyRs) are a particular type of channels located on the membranes of sarcoplasmic reticulum. They are widely expressed and their distribution in the CNS is of particular importance (Verkhratsky 2005), but here we will describe their role in the myocardium only. RyRs have a critical role in excitation-contraction coupling in striated muscles (both skeletal and cardiac). They are inextricably related to voltage-gated calcium channels (VGCC). Recently, 
several different concepts emerged that try to relate changes of phosphorylation state of both voltage-gated calcium channels and RyRs to physiological and pathological events in the myocardial cells. We will primarily describe these recent advances in ryanodine receptor research, their interaction with VGCCs and the influence of protein kinase A upon them.

\section{Ryanodine receptors - genes and expression}

So far, three types of ryanodine receptors have been isolated, RyR1-RyR3 (Zorzato et al. 1990, Hakamata et al. 1992). They are coded by three different genes, giving rise to enormous polypeptides (4872-5037 amino acids). The distribution of RyRs in the organism is generally tissue-specific: RyR1 predominates in skeletal muscles, RyR2 in the cardiac muscle, whereas RyR3 has a wide and, at a first glance, irregular distribution.

\section{Structure of ryanodine receptors}

Structurally, there are larger receptors and larger proteins than RyRs, but RyRs are the largest ion channels known to exist. Each molecule has more than 5000 amino acids, with the molecular mass of $\sim 600 \mathrm{kDa}$. Both ends of the molecule (amino- and carboxy) are on the cytosolic side of the membrane, i.e. on the outside from the sarcoplasmic reticulum lumen (Grunwald and Meissner 1995), which implies an even number of transmembrane segments. The protein itself is disproportionally divided into cytosolic ( 4000 aa) and transmembrane segment ( $\sim 1000$ aa) (Rossi and Sorrentino 2002).

Since the complete receptor is a homotetramer, composed of subunits attached at their angles, its total mass is $2.5 \mathrm{MDa}$ (Serysheva et al. 2005). Due to such an enormous size, RyRs are clearly visible under the electron microscope (the foot processes at the junction of sarcoplasmic reticulum and T-tubules).

\section{Voltage-gated calcium channels}

There are several existing nomenclature systems related to VGCC and this produces a lot of confusion. Throughout this paper, we shall use the most recent one (Catterall 2000). The voltage-gated calcium channels in the heart are usually designated as L-type calcium channels because after the activation their current is longlasting. Due to their enormous importance in cardiovascular pathology, large groups of blocking drugs have been developed. Structurally, these calcium blockers can be divided into phenylalkylamines, dihydropyridines and benzothiazepines. This explains another name used
Table 1. The nomenclature(s) used for describing the voltagegated calcium channels. The currently used system, the system according to the alpha subunit distribution and the electrophysiological system.

\section{IUPHAR alpha subunit Electrophysiological nomenclature nomenclature nomenclature}

\begin{tabular}{lcc}
\hline$C a_{V} 1.1$ & $\alpha 1_{\mathrm{S}}$ & $\mathrm{L}$ \\
$C a_{V} 1.2$ & $\alpha 1_{\mathrm{C}}$ & $\mathrm{L}$ \\
$C a_{V} 1.3$ & $\alpha 1_{\mathrm{D}}$ & $\mathrm{L}$ \\
$C a_{V} 1.4$ & $\alpha 1_{\mathrm{F}}$ & $\mathrm{L}$ \\
$C a_{V} 2.1$ & $\alpha 1_{\mathrm{A}}$ & $\mathrm{P} / \mathrm{Q}$ \\
$C a_{V} 2.2$ & $\alpha 1_{\mathrm{B}}$ & $\mathrm{N}$ \\
$C a_{V} 2.3$ & $\alpha 1_{\mathrm{E}}$ & $\mathrm{R}$ \\
$C a_{V} 3.1$ & $\alpha 1_{\mathrm{G}}$ & $\mathrm{T}$ \\
$C a_{V} 3.2$ & $\alpha 1_{\mathrm{H}}$ & $\mathrm{T}$ \\
$C a_{V} 3.3$ & $\alpha 1_{\mathrm{I}}$ & $\mathrm{T}$ \\
\hline
\end{tabular}

for this same type of channels - dihydropyridine receptors (DHPR). According to this system, there are other types of voltage-gated calcium channels, such as $\mathrm{P} / \mathrm{Q}, \mathrm{R}, \mathrm{N}$ and T-type channels. A comparative list of these three systems is presented in Table 1.

\section{Regulation of ryanodine receptor activity}

Ryanodine is a substance originally derived from the plant Ryania sp. Initially, it was used as an insecticide, but it was soon noticed that it is also toxic for humans and animals, because of its paralytic action on skeletal and cardiac muscles. However, at the beginning it was not known why cardiac paralysis caused by ryanodine was flaccid, whereas skeletal muscle paralysis was spastic. This difference is not trivial, because it indicates essential difference in the mechanism of calcium handling in these two tissues: ryanodine blocks RyRs in the open state, thus practically emptying the sarcoplasmatic reticulum, because the calcium ions leak out. Contrary to cardiac muscle cells, the skeletal myocytes do not possess the strong membrane transport systems for elimination of $\mathrm{Ca}^{2+}$ (Fill and Copello 2002), so that free cytosolic $\left[\mathrm{Ca}^{2+}\right]$ increases, causing muscle contraction.

\section{Function of ryanodine receptors in striated muscles}

As in other types of ion channels, we can describe the selectivity, conductivity and activation properties of RyR receptors. Compared to other ion channels, their conductivity is enormous, the highest 
A)
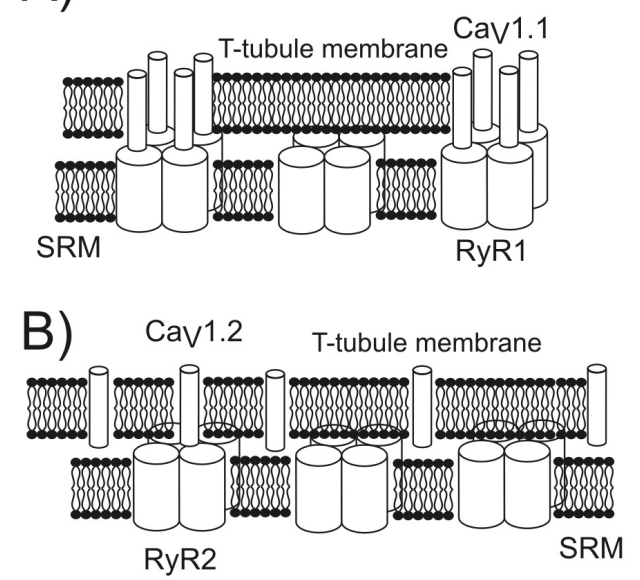

C)
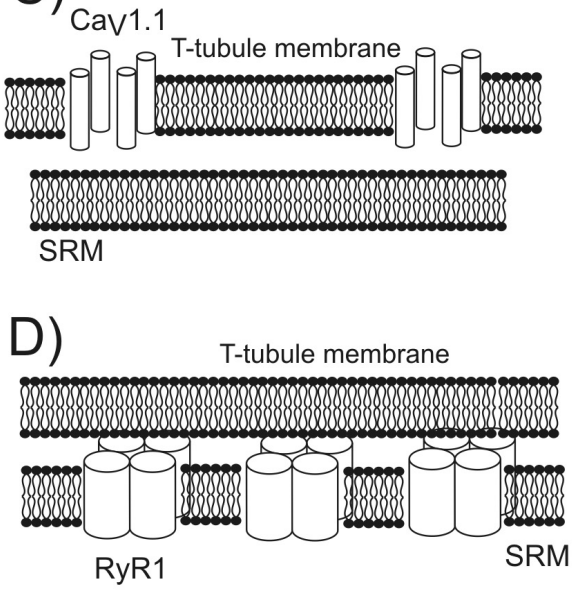

Fig. 1. Interaction and positioning of RyRs and voltagegated calcium channels in skeletal in cardiac muscle. A. In the skeletal muscle, there is an orderly association between RyR1 and Cav1.1: every other complete RyR1 channel is in contact with 4 Cav1.1 channels, each calcium channel interacting with a single RyR1 subunit. B. In cardiac muscle, there is a functional interaction of RyR2 with Cav1.2. However, their positioning is less regular, although physical interaction between them may exist (see text). C. Mutant animals without RyR1 genes are called dyspedic. The lack of RyR1 can not be compensated for by RyR2 to reestablish excitationcontraction coupling. D. Mutant animals without $\mathrm{Ca}_{v} 1.1$ are called dysgenic. SRM - sarcoplasmic reticulum membrane. known, in the order of $\mathrm{nS}$, when the charge carriers are monovalent cations. RyRs are moderately selective cation channels (only 6 times more permeable to calcium than to potassium). For comparison, $\mathrm{Ca}_{\mathrm{V}} 1 . \mathrm{x}$ channels are 20 times more selective for calcium over potassium (Chen et al. 1997).

RyRs should not be considered as isolated structures, because they are connected to a number of proteins from both cytosolic and luminal side (Zhang et al. 1997). Here, we will primarily deal with their interaction with $\mathrm{Ca}_{\mathrm{V}}$ 1.x channels. There is a functional selectivity in the interaction between subtypes of these channels (Nakai et al. 1997, because RyR1 in skeletal muscles interacts with $\mathrm{Ca}_{\mathrm{V}} 1.1$, whereas RyR2 interacts with $\mathrm{Ca}_{\mathrm{V}} 1.2$ in the myocardium (Sun et al. 1995, Ertel et al. 2000).

Structurally, this is confirmed by the organization of RyRs and $\mathrm{Ca}_{\mathrm{V}} 1 . \mathrm{x}$, which is much more regular in the skeletal muscles: RyR1 and $\mathrm{Ca}_{\mathrm{V}} 1.1$ are organized in tetrads, so that one $\mathrm{Ca}_{\mathrm{V}} 1.1$ is connected to each of the four RyR1 subunits (Franzini-Armstrong 2004). In the cardiac muscle, the organization is irregular, i.e. the distribution of $\mathrm{Ca}_{\mathrm{V}} 1.2$ above adjacent RyR2s is haphazard. In addition, their ratio is significantly lower: there are 4-10 times more $\mathrm{Ca}_{\mathrm{V}} 1.2$ than RyR2s, i.e. only 10-25\% of calcium channels are in contact with RyRs (Bers and Stiffel 1993).

Due to these structural differences, a different mechanism of excitation-contraction coupling exists in these two types of striated muscles. It is a well-known fact that calcium ions in extracellular solution bathing the tissue are essential for cardiac, but not for skeletal muscles (Armstrong et al. 1972, Dirksen and Beam 1999). Thus membrane potential change per se is not sufficient for cardiac contraction since calcium influx is also required (Franzini-Armstrong and Protasi 1997).

Except for this anterograde interaction between $\mathrm{Ca}_{\mathrm{V}} 1.1$ and RyR1 (a synonym for excitation-contraction coupling), a retrograde interaction between them also exists, because after stimulation, RyR1 can increase the activity of its corresponding $\mathrm{Ca}_{\mathrm{V}} 1.1$. It has been shown that the effect is RyR1 specific, because RyR2 cannot replace it either in the orthograde (cannot be activated by depolarization only) or in retrograde coupling (Nakai et al. 1997).

However, as much as it is simplistic to assume that $\mathrm{Ca}_{\mathrm{V}} 1.2$ and cardiac RyR2 are not physically connected, recent literary data have overthrown this assumption. It has been shown that cross-reactions do occur, both for peptide A (Dulhunty et al. 2004) and peptide C (Dulhunty et al. 2005); these peptides are the fragments of voltage-gated calcium channels. The interaction of RyRs and $\mathrm{Ca}_{\mathrm{V}} 1 . \mathrm{x}$ is shown in Figure 1.

\section{$V G C C$ and $P K A$}

For their relationship to RyR, it is important to describe the modulation of $\mathrm{Ca}_{\mathrm{V}} 1 . \mathrm{x}$ by sympathetic, $\beta$-adrenergic receptor mediated stimulation. The stimulation of $\beta$-adrenergic receptors and PKA produces a significant increase in calcium current through $\mathrm{Ca}_{\mathrm{V}} 1.2$ (Sculptoreanu et al. 1993). This could be a part of the mechanism that explains the positive inotropic (increase 


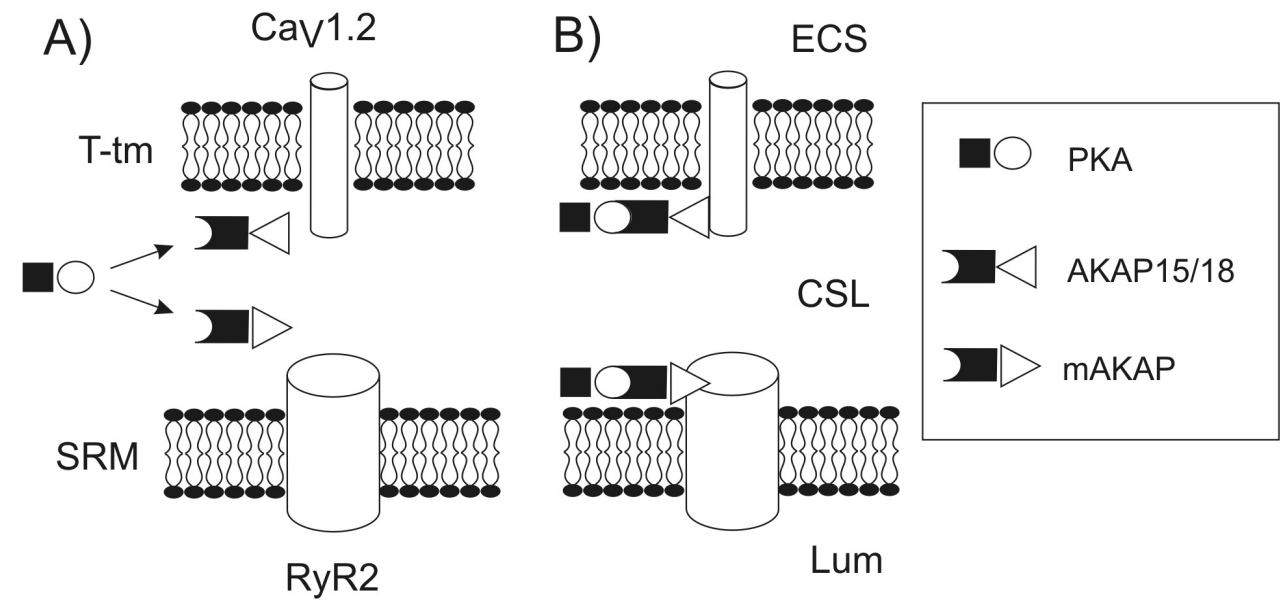

Fig. 2. A. The same enzyme, PKA, can be differentially targeted to RyR2 or Cav1.2. B. To achieve this, different adaptor proteins are used to localize the effect of PKA to the desired protein. It is still a matter of debate whether dissociation of catalytic from regulatory subunit of PKA is necessary. T-tm - t-tubule membrane, ECS - extracellular space, CSL - cytosol, SRM sarcoplasmic reticulum membrane, Lum - sarcoplasmic reticulum lumen.

in the contraction strength) and lusitropic effects (increase in the rate of heart relaxation) of the sympathetic system on working musculature of the heart. At the single channel level, this is manifested as an increase in open channel probability (Yue et al. 1990).

It was found in both skeletal and cardiac muscles, that the moment of initiation of the PKA effect was too rapid if PKA were simply floating free in the cytosol. It is believed that PKA is anchored to the cellular membrane by A-kinase anchoring proteins (AKAPs), which both raise the local concentration of the enzyme and localize it in the close proximity of its targets (Johnson et al. 1994), therefore acting as efficient means to control the spatiotemporal resolution of cAMPresponsive phosphorylation events (Gao et al. 1997). AKAPs are also used to bring PKA into the close vicinity of RyR2. The specificity of the same enzyme for acting on two different molecules is conferred by different adaptor proteins. Thus, in skeletal muscles, AKAP15/18 is the one that attaches PKA to $\mathrm{Ca}_{V} 1.1$ (Gray et al. 1997). Both AKAP79 (Gao et al. 1997) and AKAP15/18 (Fraser et al. 1998) are candidates for targeting PKA to $\mathrm{Ca}_{\mathrm{V}} 1.2$.

\section{Ryanodine receptors and $P K A$}

The targets of PKA in cardiac muscle cells are manifold (phospholamban, troponin I, myosin protein $\mathrm{C}$ ): here, we deal only with $\mathrm{Ca}_{\mathrm{V}} 1.2$ and RyR2. B-agonistinduced phosphorylation of RyR2 was observed in intact myocytes (Shen 2006), as well as in isolated myocytes, in which RyR2 activity was stimulated by isoproterenol and blocked by propranolol (Yoshida et al. 1992). Various enzymes are involved in this, the most important being protein kinase A (PKA). It is brought to a close proximity of its target on RyR2, Ser-2809 (Witcher et al. 1991), by an A kinase adaptor protein, mAKAP, (aka AKAP100), which colocalizes with RyR2 (Yang et al. 1998). The compartmentalization of PKA effect on VGCCs and RyRs is shown in Figure 2.

Thus, we have shown how PKA comes into proximity of RyRs. What remains to be seen is how its effect is converted into higher RyR activity. In order to do so, a new player must be introduced into the game.

Various cells in the human body contain a group of proteins designated as FKBPx (FK-506 binding proteins with molecular weight $\mathrm{x}$ ), because they bind a drug called FK-506. The smaller, archetypal members are FKBP12 and FKBP12.6. In skeletal muscles, both FKBP12 and FKBP12.6 bind to RyR (Timerman et al. 1993), whereas in the myocardium only a slightly heavier isoform, FKBP12.6, binds to RyR2 (Timerman et al. 1996).

This is important for the explanation of the $\beta_{1}$-adrenergic agonist action on the heart: acting via cAMP, they activate PKA, which phosphorylates RyR2. While it is bound, FKBP12.6 inhibits RyR2. Phosphorylation of RyR2 by PKA causes FKBP12.6 to unbind from RyR2 (Marx et al. 2000), which then becomes more sensitive to the cytosolic $\left[\mathrm{Ca}^{2+}\right]$. The effect is rapidly reversed by phosphatases, making it a component of a physiological mechanism for inotropic sympathetic effect. Fortunately, the effect of $\beta_{1}$-agonists still does not enable RyR2 to be activated at the normal diastolic $\left[\mathrm{Ca}^{2+}\right]$ of $10^{-7} \mathrm{M}$, otherwise, we would be susceptible to life-threatening arrhythmia even at moderate physical exertion (Marks 2003).

The unusual phenomenon related to RyRs is that, under norma conditions, they do not operate as isolated units. Instead, there is a physical and functional connection between them, producing a two-dimensional network in the membrane. This has been shown in both skeletal (Marx et al. 1998) and cardiac muscle (Marx et al. 2001). It means that RyRs create a higher-order entity, 
opening and closing at the same time, which is called coupled gating. This system of coupled gating of RyR2s works while FKBP12.6 is bound to RyR2. However, phosphorylation of RyR2 by PKA unbinds FKBP12.6 and channels start to operate individually. In certain individuals, this effect, combined with the higher sensitivity of phosphorylated RyR2 to calcium, can have serious detrimental consequences.

\section{Ryanodine receptors in cardiac pathology}

At least two conditions can be related to a change (inborn or acquired) in activity of RyR2 in the heart. These include catecholamine-provoked ventricular tachycardia and heart failure.

\section{Ryanodine receptors and catecholamine-provoked ventricular tachycardia}

Sudden cardiac death is a term that indicates death due to cardiac causes, heralded by abrupt loss of consciousness within $1 \mathrm{~h}$ after the onset of acute symptoms, in an individual who may have known about his preexisting heart disease but in whom the time and mode of death are unexpected (Myerburg 2001). This can occur in people with chronic heart failure, but also in children and healthy adults without previously proven cardiac disease, cardiac arrest being the first (and the last) clinical manifestation of underlying disease. In a certain percentage of cases, no visible cause of death can be found on autopsy (Chugh et al. 2004). Therefore, it should be sought for at the molecular level (Swan et al. 1999). The results of post mortem analysis show that about $14 \%$ of sudden cardiac deaths can be ascribed to RyR2 mutations (Tester et al. 2004).

These persons (even at an early age) become susceptible to bouts of ventricular arrhythmias during physical exertion (Lehnart et al. 2004). Structurally, there is nothing wrong with their hearts, but increased sympathetic stimulation during exercise can cause sudden cardiac death. Some of the mutations decrease the binding affinity of mutated RyR channels to FKBP12.6. In non-stimulated state (no PKA activity), these channels behave normally. Phosphorylation, however, causes a 10 fold increase in probability of theiropening which could account for diastolic calcium leakage and triggering of lethal arrythmias.

\section{Ryanodine receptors and heart failure}

In heart failure, several changes occur in the heart cells: prolonged action potential, slower $\left[\mathrm{Ca}^{2+}\right]$ systolic rise (longer time to peak), lower maximal amplitude of the calcium systolic pulse, as well as higher resting $\left[\mathrm{Ca}^{2+}\right]$ in the diastole, the latter effect being even more pronounced by inotropic drugs (Jiang et al. 2002). These events have logical consequences to cardiac contraction and relaxation: the systole is slower and weaker, whereas the diastolic relaxation is incomplete. We will try to focus on events in the diastole and indicate a possible role of RyR2 there in.

People with heart failure have an elevated level of circulating catecholamines (Kinugawa et al. 1996). The prolonged activation of $\beta_{1}$-adrenergic receptors produces their desensitization and down-regulation (Bristow et al. 1982). Nevertheless, beta-blockers are used in the treatment of heart failure (Gottlieb et al. 2002), although their beneficial effect is contrary to common sense (Marks et al. 2002): why would the drugs that weaken cardiac contraction be useful for the heart that is already weakened by disease?

To provide an explanation for this, we shall focus on the previously mentioned higher diastolic $\left[\mathrm{Ca}^{2+}\right]$. In theory, it could be explained either by lower activity of the systems that remove cytosolic calcium released during diastole (Yano et al. 2005), primarily by $\mathrm{Ca}^{2+}$ ATPase, or by persistent leakage of $\mathrm{Ca}^{2+}$ through RyR2 that should be closed during the diastole (Shannon et al. 2003). It has been shown that, in heart failure, activity of PKA is high. This is combined with lower phosphatase activity (Marx et al. 2000), leading to hyperphosphorylation of RyR2s. This seems to be a critical point that accounts for the beneficial effect of beta-blockers: blockade of chronic catecholaminergic activity and reduction of PKA activity allow for dephosphorylation of RyR2s. When reverted into the normal state, they rebind FKBP12.6 which has two consequences: it reduces the calcium sensitivity and re-enables RyR2 to operate as a unit, i.e. restores the coupled gating. Both of these effects reduce the possibility for stochastic activation of RyR2 during the diastole. This prevents diastolic calcium leakage (leaving more calcium in the SR for a stronger systole) and reduces the diastolic $\left[\mathrm{Ca}^{2+}\right]$, thus preventing life-threatening ventricular arrhythmias.

This explanation sounds reasonable and wellsupported by experimental data. However, many studies have challenged it. It was found that FKBP12.6 binds to RyR2 equally well regardless of the level of phosphorylation and that it even binds to RyR2 mutated in the way to imitate constitutive hyperphosphorylation (Jiang et al. 2002). Furthermore, no differences have been 
A1) Coupled

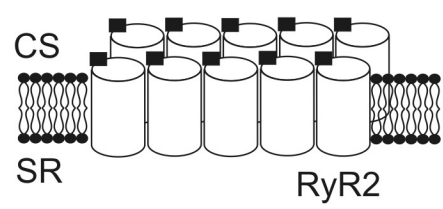

A2)

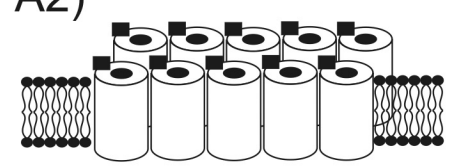

B1) Hyperphospho

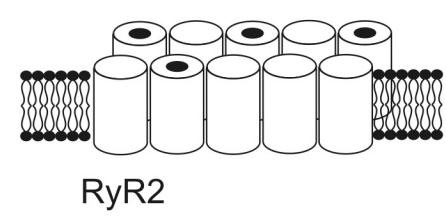

B2)

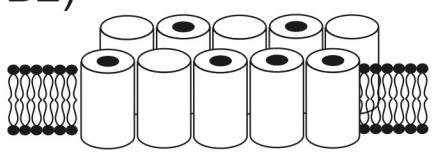

Fig. 3. A1. In the healthy individual, with normal level of RyR2 phosphorylation, FKBP12.6 is bound to RyR2 (for the sake of simplicity, only one FKBP12.6 per RyR2 is shown, although actually there are four, each bound to one RyR2 subunit). A2. When activated, RyR2

- FKBP12.6 then operate in concert, opening and closing simultaneously (during systole and diastole, respectively). B1. In hyperphosporylated state, FKBP12.6 dissociates from RyR2 and the coupling is lost. For this reason, some RyR2 channels can open even without stimulation, during diastole, giving rise to a tendency to lethal arrhythmias. B2. In addition, not all channels open when they should, producing changes in calcium handling during heart failure. CS cytosolic side, SR - sarcoplasmic reticulum lumen. found in the level of phosphorylation of RyR2 in healthy or diseased hearts. The role of RyR2 phosphorylation in diastolic $\mathrm{Ca}^{2+}$ leakage was denied and instead ascribed to increased $\left[\mathrm{Ca}^{2+}\right]$ in SR by increased uptake ( $\mathrm{Li}$ et al. 2002). The effect of PKA on RyR phosphorylation and its interaction with FKBP12.6 is shown in Figure 3.

\section{Conclusion}

The data presented in this paper indicate that investigating a single molecule, however well its role may be defined, is often misleading. Many convincing truths have been questioned and discarded, once again showing that nature's mechanisms are not limited to only one type of cells, but are universally applicable in different cells of the organism, to the horror of those that try to classify them. Ryanodine receptors are a good example of this. A large body of data has accumulated about their interactions with many different proteins, both from the cytosolic (as some of them are described here) and luminal side. More and more mutations in the constituents of this complex system are related to human diseases. Converted into clinical setting, given the high risk of sudden death and the efficacy of beta-blockers or implantable cardioverter defibrillators in the therapy of catecholamine-provoked ventricular tachycardia, it should become routine to perform genetic screening, early diagnosis, and subsequent preventive strategies in the treatment of this condition (Postma et al. 2005). The idea that aberrant $\mathrm{Ca}^{2+}$ release from RyR2 can lead to arrhythmogenic activity was shown in hearts of patients with atrial fibrillation, with hyperphosphorylation and decreased FKBP12.6 binding to RyR2 in atrial myocytes (Vest et al. 2005). Recently, it has been unequivocally shown in patients with heart failure that the well-known beneficial effect of beta-blockers occurs through stabilization of RyR2 function in failing hearts (Reiken et al. 2003). This finding is particularly distressing in the light of clinical evidence that many of such patients do not receive this therapy, even when they have no contraindications. In addition, recent pharmacological advances provide the opportunity for practical clinical use of these findings. The benzothiazepine derivatives that induce binding of FKBP12.6 to RyR2 had beneficial effects in experimental models of heart failure, manifested as a significant increase in fractional shortening and ejection fraction, increase in peak $\mathrm{dP} / \mathrm{dt}$ and decrease in end-diastolic ventricular pressure (Kohno et al. 2003, Wehrens et al. 2005), as well as in models of triggered arrythmias in heart failure and catecholamineprovoked ventricular tachycardia (Wehrens et al. 2004). These drugs may thus constitute a novel class that is directed to gene-defect specific treatment of arrythmias. Hence, a better understanding of the role of ryanodine receptors in the pathophysiology of these conditions could lead us to the correct path in the search for improved therapy. Many of the new concepts work well at the molecular level. Time will show to what extent the initial simplistic assumptions become more complicated in its ultimate setting, i.e. in the diseased patient.

\section{Conflict of Interest}

There is no conflict of interest. 


\section{Abbreviations}

VGCC - voltage-gated calcium channel, RyR ryanodine receptor, PKA - protein kinase A, DHPR dihydropyridine receptor, AKAP - A kinase binding protein, FKBP - FK-506 binding protein.

\section{Acknowledgements}

This work was supported by Academy of Sciences of the Czech Republic Research Project AVOZ 50110509.

\section{References}

ARMSTRONG CM, BEZANILLA FM, HOROWICZ P: Twitches in the presence of ethylene glycol bis(-aminoethyl ether)-N,N'-tetracetic acid. Biochim Biophys Acta 267: 605-608, 1972.

BERS DM, STIFFEL VM: Ratio of ryanodine to dihydropyridine receptors in cardiac and skeletal muscle and implications for E-C coupling. Am J Physiol 264: C1587-C1593, 1993.

BRISTOW M, GINSBURG R, MINOBE W, CUBICCIOTTI R, SAGEMAN W, LURIE K, BILLINGHAM M, HARRISON D, STINSON E: Decreased catecholamine sensitivity and beta-adrenergic-receptor density in failing human hearts. $N$ Engl J Med 307: 205-211, 1982.

CATTERALL WA: Structure and regulation of voltage-gated $\mathrm{Ca}^{2+}$ channels. Annu Rev Cell Dev Biol 16: 521-555, 2000.

CHEN SRW, LI X, EBISAWA K, ZHANG L: Functional characterization of the recombinant type $3 \mathrm{Ca}^{2+}$ release channel (ryanodine receptor) expressed in HEK293 cells. J Biol Chem 272: 24234-24246, 1997.

CHUGH SS, SENASHOVA O, WATTS A, TRAN PT, ZHOU Z, GONG Q, TITUS JL, HAYFLICK SJ: Postmortem molecular screening in unexplained sudden death. $J$ Am Coll Cardiol 43: 1625-1629, 2004.

DIRKSEN RT, BEAM KG Role of calcium permeation in dihydropyridine receptor function. Insights into channel gating and excitation-contraction coupling. J Gen Physiol 114: 393-403, 1999.

DULHUNTY AF, CURTIS SM, CENGIA L, SAKOWSKA M, CASAROTTO MG: Peptide fragments of the dihydropyridine receptor can modulate cardiac ryanodine receptor channel activity and sarcoplasmic reticulum $\mathrm{Ca}^{2+}$ release. Biochem J 379: 161-172, 2004.

DULHUNTY AF, KARUNASEKARA Y, CURTIS SM, HARVEY PJ, BOARD PG, CASAROTTO MG: The recombinant dihydropyridine receptor II-III loop and partly structured ' $\mathrm{C}$ ' region peptides modify cardiac ryanodine receptor activity. Biochem J 385: 803-813, 2005.

ERTEL EA, CAMPBELL KP, HARPOLD MM, HOFMANN F, MORI Y, PEREZ-REYES E, SCHWARTZ A, SNUTCH TP, TANABE T, BIRNBAUMER L: Nomenclature of voltage-gated calcium channels. Neuron 25: 533-535, 2000.

FILL M, COPELLO JA: Ryanodine receptor calcium release channels. Physiol Rev 82: 893-922, 2002.

FRANZINI-ARMSTRONG C: Functional implications of RyR-dHPR relationships in skeletal and cardiac muscles. Biol Res 37: 507-512, 2004.

FRANZINI-ARMSTRONG C, PROTASI F: Ryanodine receptors of striated muscles: a complex channel capable of multiple interactions. Physiol Rev 77: 699-729, 1997.

FRASER ID, TAVALIN SJ, LESTER LB, LANGEBERG LK, WESTPHAL AM, DEAN RA, MARRION NV, SCOTT JD: A novel lipid-anchored A-kinase anchoring protein facilitates cAMP-responsive membrane events. EMBO J 17: 2261-2272, 1998.

GAO T, YATANI A, DELL'ACQUA ML, SAKO H, GREEN SA, DASCAL N, SCOTT JD, HOSEY MM: cAMPdependent regulation of cardiac L-type $\mathrm{Ca}^{2+}$ channels requires membrane targeting of PKA and phosphorylation of channel subunits. Neuron 19: 185-196, 1997.

GOTTLIEB SS, FISHER ML, KJEKSHUS J, DEEDWANIA P, GULLESTAD L, VITOVEC J, WIKSTRAND J: Tolerability of \{beta\}-blocker initiation and titration in the metoprolol CR/XL randomized intervention trial in congestive heart failure (MERIT-HF). Circulation 105: 1182-1188, 2002.

GRAY PC, TIBBS VC, CATTERALL WA, MURPHY BJ: Identification of a 15-kDa cAMP-dependent protein kinaseanchoring protein associated with skeletal muscle L-type calcium channels. J Biol Chem 272: 6297-6302, 1997. 
GRUNWALD R, MEISSNER G: Lumenal sites and C terminus accessibility of the skeletal muscle calcium release channel (ryanodine receptor). J Biol Chem 270: 11338-11347, 1995.

HAKAMATA Y, NAKAI J, TAKESHIMA H, IMOTO K: Primary structure and distribution of a novel ryanodine receptor/calcium release channel from rabbit brain. FEBS Lett 312: 229-235, 1992.

JIANG MT, LOKUTA AJ, FARRELL EF, WOLFF MR, HAWORTH RA, VALDIVIA HH: Abnormal $\mathrm{Ca}^{2+}$ release, but normal ryanodine receptors, in canine and human heart failure. Circ Res 91: 1015-1022, 2002.

JOHNSON BD, SCHEUER T, CATTERALL WA: Voltage-dependent potentiation of L-type $\mathrm{Ca}^{2+}$ channels in skeletal muscle cells requires anchored cAMP-dependent protein kinase. Proc Natl Acad SciUSA 91: 11492-11496, 1994.

KINUGAWA T, OGINO K, KITAMURA H, SAITOH M, OMODANI H, OSAKI S, HISATOME I, MIYAKODA H: Catecholamines, renin-angiotensin-aldosterone system, and atrial natriuretic peptide at rest and during submaximal exercise in patients with congestive heart failure. Am J Med Sci 312: 110-117, 1996.

KOHNO M, YANO M, KOBAYASHI S, DOI M, ODA T, TOKUHISA T, OKUDA S, OHKUSA T, KOHNO M, MATSUZAKI M: A new cardioprotective agent, JTV519, improves defective channel gating of ryanodine receptor in heart failure. Am J Physiol 284: H1035-H1042, 2003.

LEHNART SE, WEHRENS XHT, MARKS AR: Calstabin deficiency, ryanodine receptors, and sudden cardiac death. Biocheml Biophys Res Commun 322: 1267-1279, 2004.

LI Y, KRANIAS EG, MIGNERY GA, BERS DM: Protein kinase a phosphorylation of the ryanodine receptor does not affect calcium sparks in mouse ventricular myocytes. Circ Res 90: 309-316, 2002.

MARKS AR: A guide for the perplexed: towards an understanding of the molecular basis of heart failure. Circulation 107: 1456-1459, 2003.

MARKS AR, REIKEN S, MARX SO: Progression of heart failure: is protein kinase a hyperphosphorylation of the ryanodine receptor a contributing factor? Circulation 105: 272-275, 2002.

MARX SO, ONDRIAS K, MARKS AR: Coupled gating between individual skeletal muscle $\mathrm{Ca}^{2+}$ release channels (ryanodine receptors). Science 281: 818-821, 1998.

MARX SO, GABURJÁKOVÁ J, GABURJÁKOVÁ M, HENRIKSON C, ONDRIÁŠ K, MARKS AR: Coupled gating between cardiac calcium release channels (ryanodine receptors). Circ Res 88: 1151-1158, 2001.

MARX SO, REIKEN S, HISAMATSU Y, JAYARAMAN T, BURKHOFF D, ROSEMBLIT N, MARKS AR: PKA phosphorylation dissociates FKBP12.6 from the calcium release channel (ryanodine receptor): defective regulation in failing hearts. Cell 101: 365-376, 2000.

MYERBURG RJ, CASTELLANOS A. Cardiovascular collapse, cardiac arrest and sudden cardiac death. In: Harrison's Principles of Internal Medicine. BRAUNWALD E, FAUCI AS, KASPER DL, HAUSER SL, LONGO DL, JAMESON LJ (eds), McGraw-Hill, New York, 2001, pp. 228-233.

NAKAI J, OGURA T, PROTASI F, FRANZINI-ARMSTRONG C, ALLEN PD, BEAM KG: Functional nonequality of the cardiac and skeletal ryanodine receptors. Proc Natl Acad Sci USA 94: 1019-1022, 1997.

POSTMA AV, DENJOY I, KAMBLOCK J, ALDERS M, LUPOGLAZOFF J-M, VAKSMANN G, DUBOSQ-BIDOT L, SEBILLON P, MANNENS MMAM, GUICHENEY P, WILDE AAM: Catecholaminergic polymorphic ventricular tachycardia: RYR2 mutations, bradycardia, and follow up of the patients. J Med Genet 42: 863-870, 2005.

REIKEN S, WEHRENS XHT, VEST JA, BARBONE A, KLOTZ S, MANCINI D, BURKHOFF D, MARKS AR: \{beta\}-Blockers restore calcium release channel function and improve cardiac muscle performance in human heart failure. Circulation 107: 2459-2466, 2003.

ROSSI D, SORRENTINO V: Molecular genetics of ryanodine receptors $\mathrm{Ca}^{2+}$-release channels. Cell Calcium 32: $307-$ $319,2002$.

SCULPTOREANU A, ROTMAN E, TAKAHASHI M, SCHEUER T, CATTERALL W: Voltage-dependent potentiation of the activity of cardiac L-type calcium channel $\alpha 1$ subunits due to phosphorylation by cAMPdependent protein kinase. Proc Natl Acad Sci USA 90: 10135-10139, 1993.

SERYSHEVA, II, HAMILTON SL, CHIU W, LUDTKE SJ: Structure of $\mathrm{Ca}^{2+}$ release channel at 14 A resolution. $J$ Mol Biol 345: 427-431, 2005. 
SHANNON TR, POGWIZD SM, BERS DM: Elevated sarcoplasmic reticulum $\mathrm{Ca}^{2+}$ leak in intact ventricular myocytes from rabbits in heart failure. Circ Res 93: 592-594, 2003.

SHEN JX: Isoprenaline enhances local $\mathrm{Ca}^{2+}$ release in cardiac myocytes. Acta Pharmacol Sin 27: 927-932, 2006.

SUN XH, PROTASI F, TAKAHASHI M, TAKESHIMA H, FERGUSON DG, FRANZINI-ARMSTRONG C: Molecular architecture of membranes involved in excitation-contraction coupling of cardiac muscle. $J$ Cell Biol 129: 659-671, 1995.

SWAN H, PIIPPO K, VIITASALO M, HEIKKILA P, PAAVONEN T, KAINULAINEN K, KERE J, KETO P, KONTULA K, TOIVONEN L: Arrhythmic disorder mapped to chromosome 1q42-q43 causes malignant polymorphic ventricular tachycardia in structurally normal hearts. J Am Coll Cardiol 34: 2035-2042, 1999.

TESTER DJ, SPOON DB, VALDIVIA HH, MAKIELSKI JC, ACKERMAN MJ: Targeted mutational analysis of the RyR2-encoded cardiac ryanodine receptor in sudden unexplained death: a molecular autopsy of 49 medical examiner/coroner's cases. Mayo Clin Proc 79: 1380-1384, 2004.

TIMERMAN A, OGUNBUMNI E, FREUND E, WIEDERRECHT G, MARKS A, FLEISCHER S: The calcium release channel of sarcoplasmic reticulum is modulated by FK-506-binding protein. Dissociation and reconstitution of FKBP-12 to the calcium release channel of skeletal muscle sarcoplasmic reticulum. $J$ Biol Chem 268: 22992-22999, 1993.

TIMERMAN AP, ONOUE H, XIN H-B, BARG S, COPELLO J, WIEDERRECHT G, FLEISCHER S: Selective binding of FKBP12.6 by the cardiac ryanodine receptor. J Biol Chem 271: 20385-20391, 1996.

VERKHRATSKY A: Physiology and pathophysiology of the calcium store in the endoplasmic reticulum of neurons. Physiol Rev 85: 201-279, 2005.

VEST JA, WEHRENS XH, REIKEN SR, LEHNART SE, DOBREV D, CHANDRA P, DANILO P, RAVENS U, ROSEN MR, MARKS AR: Defective cardiac ryanodine receptor regulation during atrial fibrillation. Circulation 111: 2025-2032, 2005.

WEHRENS XH, LEHNART SE, REIKEN SR, DENG SX, VEST JA, CERVANTES D, COROMILAS J, LANDRY DW, MARKS AR: Protection from cardiac arrhythmia through ryanodine receptor-stabilizing protein calstabin2. Science 304: 292-296, 2004.

WEHRENS XH, LEHNART SE, REIKEN S, VAN DER NAGEL R, MORALES R, SUN J, CHENG Z, DENG SX, DE WINDT LJ, LANDRY DW, MARKS AR: Enhancing calstabin binding to ryanodine receptors improves cardiac and skeletal muscle function in heart failure. Proc Natl Acad Sci USA 102: 9607-9612, 2005.

WITCHER D, KOVACS R, SCHULMAN H, CEFALI D, JONES L: Unique phosphorylation site on the cardiac ryanodine receptor regulates calcium channel activity. J Biol Chem 266: 11144-11152, 1991.

YANG J, DRAZBA JA, FERGUSON DG, BOND M: A-kinase anchoring protein 100 (AKAP100) is localized in multiple subcellular compartments in the adult rat heart. J Cell Biol 142: 511-522, 1998.

YANO M, IKEDA Y, MATSUZAKI M: Altered intracellular $\mathrm{Ca}^{2+}$ handling in heart failure. $J$ Clin Invest 115: 556-564, 2005.

YOSHIDA A, TAKAHASHI M, IMAGAWA T, SHIGEKAWA M, TAKISAWA H, NAKAMURA T: Phosphorylation of ryanodine receptors in rat myocytes during $\beta$-adrenergic stimulation. $J$ Biochem (Tokyo) 111: 186-190, 1992.

YUE DT, HERZIG S, MARBAN E: Beta-adrenergic stimulation of calcium channels occurs by potentiation of highactivity gating modes. Proc Natl Acad Sci USA 87: 753-757, 1990.

ZHANG L, KELLEY J, SCHMEISSER G, KOBAYASHI YM, JONES LR: Complex formation between junctin, triadin, calsequestrin, and the ryanodine receptor. Proteins of the cardiac junctional sarcoplasmic reticulum membrane. J Biol Chem 272: 23389-23397, 1997.

ZORZATO F, FUJII J, OTSU K, PHILLIPS M, GREEN N, LAI F, MEISSNER G, MACLENNAN D: Molecular cloning of cDNA encoding human and rabbit forms of the $\mathrm{Ca}^{2+}$ release channel (ryanodine receptor) of skeletal muscle sarcoplasmic reticulum. J Biol Chem 265: 2244-2256, 1990. 